\title{
RANCANG BANGUN SISTEM PENDATAAN HARDWARE
}

\author{
Alvin Anzas Islami' ${ }^{1}$, Siti Ramadhani ${ }^{2)}$ \\ ${ }^{1}$ Sains Dan Teknologi, Universitas Islam Negeri Sultan Syarif Kasim, Jl. HR. Soebrantas Panam Km 15, \\ Panam, Pekanbaru \\ email: 11750115097@students.uin-suska.ac.id \\ ${ }^{2}$ Sains Dan Teknologi, Universitas Islam Negeri Sultan Syarif Kasim, Jl. HR. Soebrantas Panam Km 15, \\ Panam, Pekanbaru \\ email: siti.ramadhani@uin-suska.ac.id
}

\begin{abstract}
Abstrak
Saat ini kemajuan teknologi informasi telah memberikan dampak yang luar biasa dalam segala aspek kehidupan khusus nya PTIPD UIN SUSKA RIAU juga membutuhkan suatu teknologi informasi yang bisa membantu jalannya tugas pegawai. Dengan teknologi informasi memungkinkan data-data PTIPD UIN SUSKA RIAU dapat diolah dengan cepat dan mudah sehingga meningkatkan efektifitas dan efisiensi penyelesaian pekerjaan maupun dalam lingkup berkomunikasi dan informasi. Pengolahan dokumentasi pendataan hardaware yang dilakukan PTIPD masih dilakukan di luar sistem sehingga menyebabkan proses dokumentasi pendataan menjadi lebih lama dan kurang efisien. Solusi yang diberikan untuk mengatasi masalah tersebut yaitu dilakukan pembuatan sistem pendataan hardware. Dalam pembuatan sistem pendataan hardware yang akan dimasukan dalam sistem meliputi informasi tentang daftar barang, petugas,. Sedang perangkat lunak yang digunakan adalah DBMS (Data Base Management System) yang digunakan sebagai media penyimpanan data adalah MySql, bahasa pemrograman PHP, CSS, JavaScript dan HTML digunakan sebagai pembuatan interface, yang bertujuan mempermudah user maupun administrator dalam memanipulasi data.
\end{abstract}

Keywords: sistem informasi, petugas, barang

\begin{abstract}
Currently, advances in information technology have had a tremendous impact in all aspects of life, especially PTIPD UIN SUSKA RIAU also requires information technology that can assist employees' work. With information technology, data at PTIPD UIN SUSKA RIAU can be processed quickly and efficiently to increase the effectiveness and efficiency of completing work and the scope of communication and information. The processing of hardware data collection documentation carried out by PTIPD is still carried out outside the system, causing the data collection documentation process to be longer and less efficient. The solution given to overcome this problem is to make a hardware data collection system. Making a hardware data collection system included in the system provides information about the list of goods and officers. While the software used is a DBMS (DataBase Management System) used as a data storage medium is MySql, the programming languages PHP, CSS, JavaScript, and HTML are used as interfaces, which aim to make it easier users and administrators to manipulate data.
\end{abstract}

Keywords: information systems, officers, hardware

\section{PENDAHULUAN}

Perkembangan ilmu pengetahuan dan teknologi pada saat ini telah berkembang dengan sangat pesat mencakup segala aspek kehidupan. Pada saat ini instansi-instansi di kota Pekanbaru sudah memanfaatkan komputer sebagai alat untuk mempermudah pekerjaan karyawannya. Tidak hanya instansi, bahkan pihak-pihak universitas pun 
juga menggunakan komputer sebagai alat untuk mempermudah pekerjaan.

Berdasarkan peraturan menteri agama republik indonesia nomor 9 tahun 2013 tentang organisasi dan tata kerja Universitas Islam Negeri Sultan Syarif Kasim Riau, Pusat Teknologi Informasi dan Pangkalan Data (PTIPD) merupakan salah satu unit pelaksana teknis. PTIPD mempunyai tugas mengelola dan mengembangkan sistem informasi manajemen, pengembangan, pemeliharaan jaringan dan aplikasi, pengelolaan basis data, pengembangan teknologi lainnya dan kerjasama jaringan.

Seiring dengan berkembangnya teknologi saat ini, PTIPD UIN SUSKA RIAU juga membutuhkan suatu teknologi yang bisa membantu jalannya tugas. Dalam menjalankan tugasnya, PTIPD UIN SUSKA RIAU sudah memanfaatkan kemajuan teknologi ini dalam menangani pekerjaanpekerjaan yang ada. Baik itu demi peningkatan efektifitas dan efisiensi penyelesaian pekerjaan maupun dalam lingkup berkomunikasi dan informasi[1], [2], [11], [12], [3]-[10]. Mulai dari penggunaan perangkat lunak pengolah kata ms.excel untuk membuat dokumendokumen yang memiliki proses kalkulasi sederhana sampai dengan penggunaan perangkat lunak pengolah kata ms.word untuk menangani pembuatan dokumendokumen seperti surat menyurat atau laporan. Selain dari itu pihak PTIPD sendiri membutuhkan sebuah sistem yang dapat mendata hardware yang dimiliki.

\section{METODE PENELITIAN}

Adapun metode yang dilakukan dalam pengerjaan kerja praktik ini adalah sebagai berikut:

1. Pengumpulan Data

Beberapa langkah yang di kerjakan dalam tahap ini yaitu: a. Studi Pustaka

Studi pustaka merupakan tahap awal dalam pengumpulan data pada penelitian. Metode ini dilakukan dengan cara mencari sumber-sumber referensi pada buku, maupun jurnal yang dianggap penting dan mendukung.

b. Wawancara

Wawancara dilakukan dengan pegawai terkait sistem yang akan dibuat.

c. Pengumpulan Data dan Informasi

Pengumpulan data dan Informasi dalam bentuk wawancara dilakukan sebagai bahan untuk identifikasi dalam melihat permasalahan yang dihadapi.

2. Tahap Analisa dan Perancangan

Tahap analisa dan perancangan ini berfungsi untuk menemukan solusi terhadap masalah yang ada dan mendiskusikan dengan pembimbing kerja praktek.

3. Tahap Implementasi dan Pengujian

Tahap ini merupakan tahap penyusunan dan pemilihan perangkat keras (hardware), perangkat lunak sistem (coding) dan pengujian (testing) yang akan memberikan hasil kelayakan sistem.

\section{HASIL DAN PEMBAHASAN}

Analisa sistem merupakan suatu proses pemahaman persoalan sebelum mengambil tindakan atau mengambil suatu keputusan untuk membuat perancangan dan desain. Perancangan dan desain dilakukan setelah tahap analisa diselesaikan dan di dalamnya terdapat rincian sistem dari hasil analisa. Analisa sistem menggunakan deskripsi umum dari sistem lama dan sistem baru dengan menggunakan metode Unified Modeling Language (UML) diantaranya Use Case Diagram, Sequence Diagram, dan Deployment Diagram.

Sistem ini akan menerima input (masukan) berupa nama serta nip pengguna dan password untuk digunakan sebagai login ke sistem, data hardware termasuk data jenis hardware. Berikut Bentuk Analisis Sistem Pendataan Hardware. 


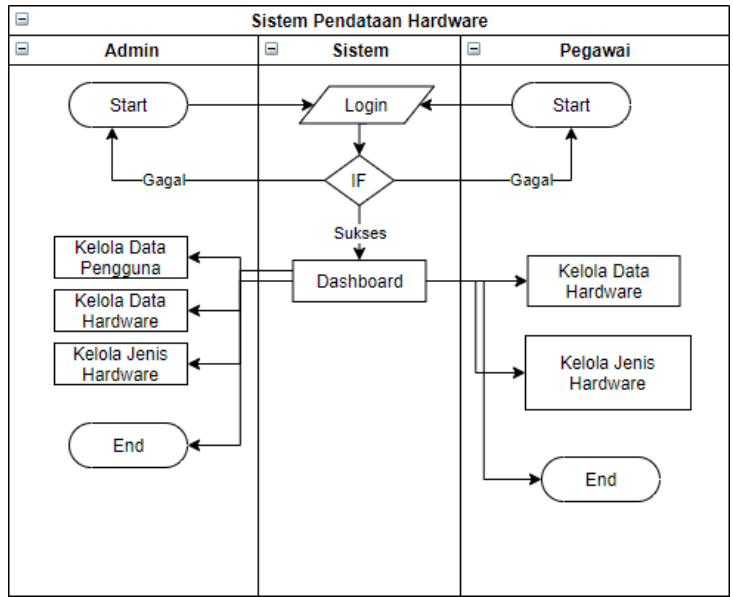

Gambar 1 Flowchart Sistem

Use Case Diagram berfungsi untuk mendeskripsikan interaksi antara suatu atau banyak aktor ke dalam sistem yang akan dibuat. Use Case Diagram juga berguna untuk mengetahui fungsi apa saja yang ada di dalam sebuah sistem dan siapa saja yang ada dalam sebuah sistem dan siapa saja yang berhak atau boleh menggunakan fungsi tersebut. Berikut adalah Use Case Diagram Sistem Pendataan Hardware.

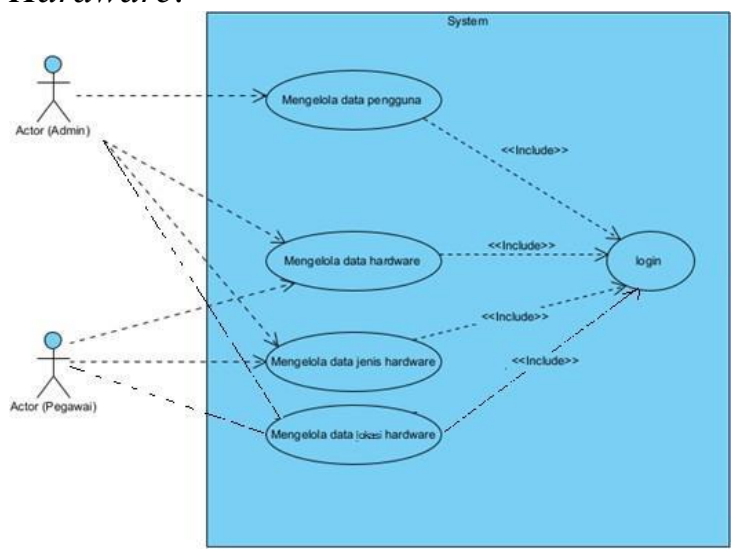

Gambar 2 Use Case Diagram Pendataan Hardware

Sistem setelah dianalisa dan dirancang, maka sistem tersebut siap diterapkan atau diimplementasikan. Tahap implementasi adalah tahap sistem informasi telah digunakan oleh pengguna. Sebelum benar-benar bisa digunakan dengan baik oleh pengguna, sistem harus melalui tahap pengujian terlebih dahulu untuk menjamin tidak ada kendala fatal yang muncul pada saat pengguna memanfaatkan sistemnya. $\begin{array}{ccr}\text { Implementasi } & \text { sistem } & \text { (system } \\ \text { implementation) } & \text { merupakan } & \text { kegiatan }\end{array}$ memperoleh dan mengintegrasikan sumber daya fisik dan konseptual yang menghasilkan suatu sistem yang bekerja. Tahap implementasi sistem (system implementation phase) adalah tahap meletakkan sistem supaya siap dioperasikan. Implementasi dari sistem Pendataan Hardware yaitu:

1. Tampilan Login

Login merupakan bagian awal sistem yang akan ditampilkan kepada pengguna. Untuk menggunakan sistem, pengguna harus terlebih dahulu memasukkan nip dan Password, kemudian klik tombol login. Jika nip dan password yang dimasukkan sesuai, maka pengguna akan masuk kedalam sistem sesuai dengan hak akses yang telah diberikan sebelumnya.

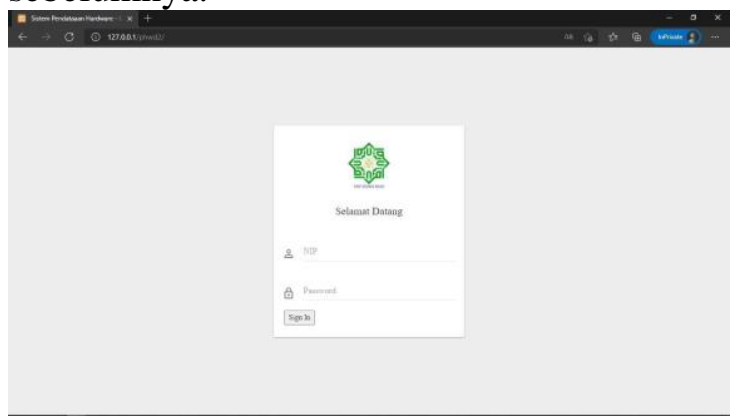

\section{Gambar 3 Tampilan Halaman Login}

2. Halaman Utama

Setelah melakukan login maka pengguna akan di arahkan ke halaman utama yang berisi menu berupa Dashboard, Menu Data Hardware, Menu Pengguna ,serta Menu Jenis Hardware apabila pengguna login sebagai Admin. Untuk login sebagai pegawai, maka akses yang didapat berupa menu Data Hardware dan menu Jenis Hardware.

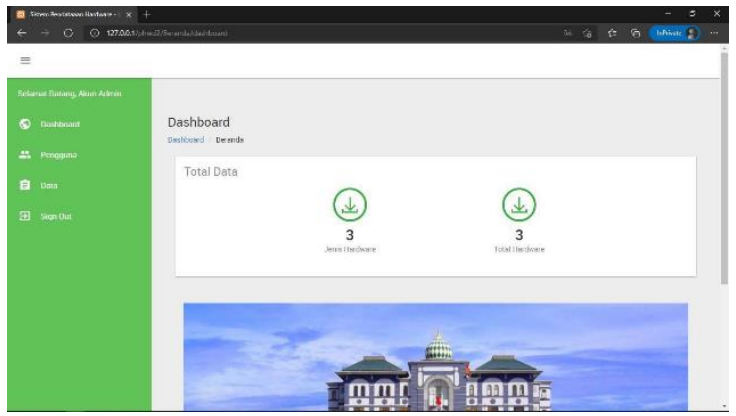

Gambar 4 Tampilan Halaman Dashboard (Login sebagai admin) 


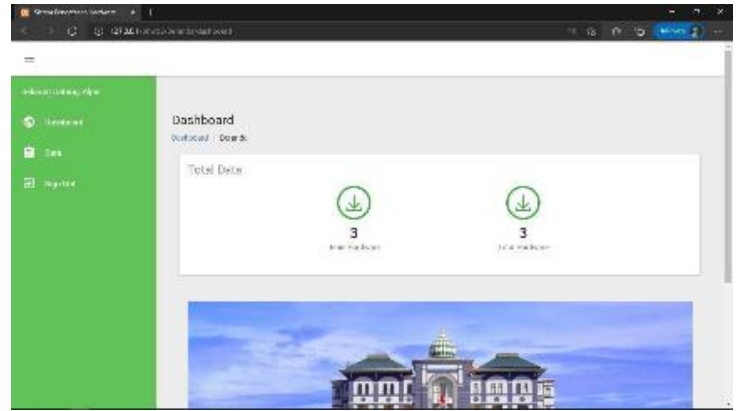

Gambar 5 Tampilan Halaman Dashboard (Login sebagai pegawai)

\section{Halaman Data Pengguna}

Setelah berada pada menu utama, Pengguna (Admin) dapat mengklik tombol Pengguna yang bertujuan untuk menambahkan data pengguna baru atau mengupdate data pengguna.

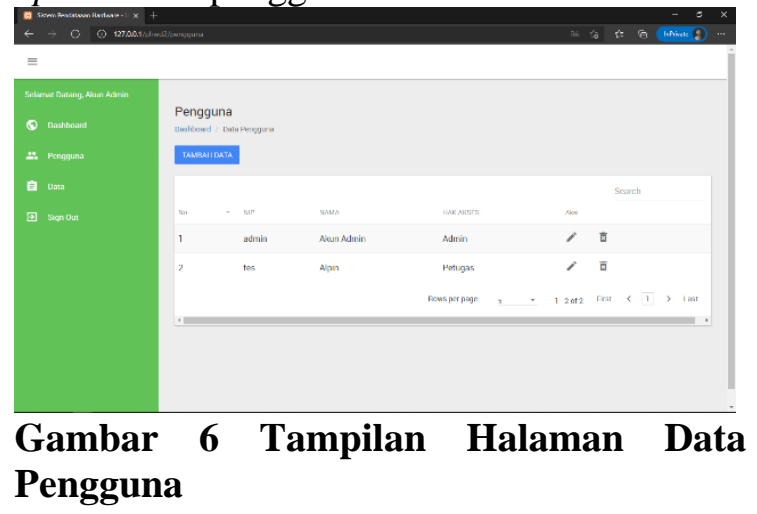

\section{Halaman Data Hardware}

Setelah berada pada menu Utama, Pengguna dapat mengklik tombol Data lalu memilih Menu Tambah Hardware yang bertujuan untuk Menambahkan Data Hardware yang baru, mengedit data hardware yang telah ada dan menghapus data hardware yang telah ditambahkan sebelumnya serta mencetak laporan dari data hardware yang ada.

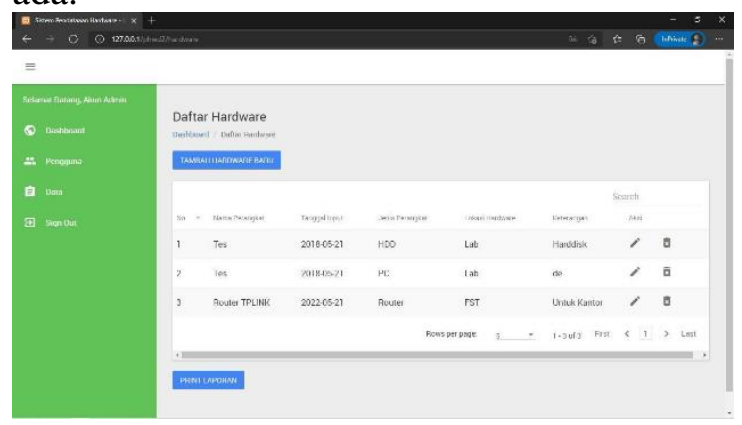

Gambar 7 Tampilan Halaman Data Hardware

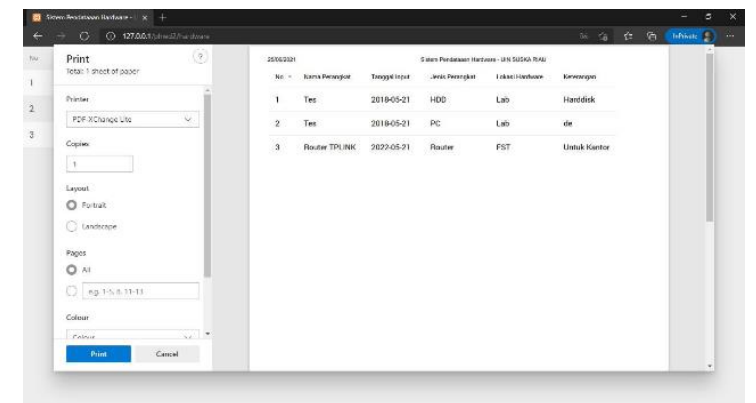

Gambar 8 Bentuk Laporan Data Hardware untuk di print

\section{Halaman Data Jenis Hardware}

Setelah berada pada menu Utama, Pengguna dapat mengklik tombol Data lalu memilih menu Tambah Jenis Hardware yang pengguna bisa menambahkan data jenis hardware yang digunakan, mengedit data jenis hardware atau menghapus data jenis hardware yang diinginkan.

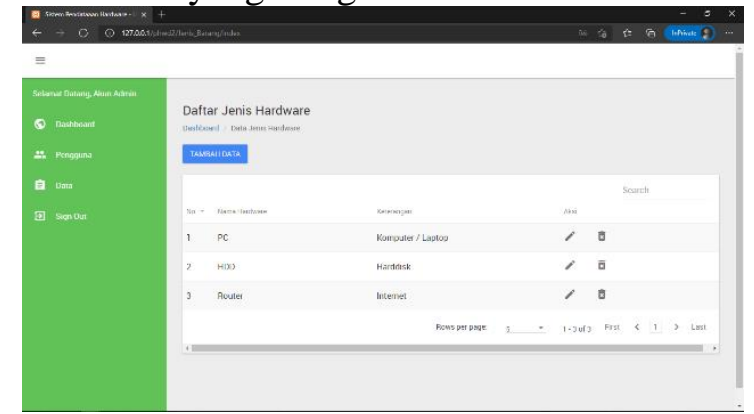

\section{Gambar 9 Tampilan Halaman Data Jenis Hardware}

\section{Halaman Data Lokasi}

Setelah berada pada menu Utama, Pengguna dapat mengklik tombol Data lalu memilih menu Lokasi Penempatan Hardware yang pengguna bisa menambahkan data lokasi penempatan hardware, mengedit data lokasi penempatan atau menghapus data lokasi penempatan yang diinginkan. 


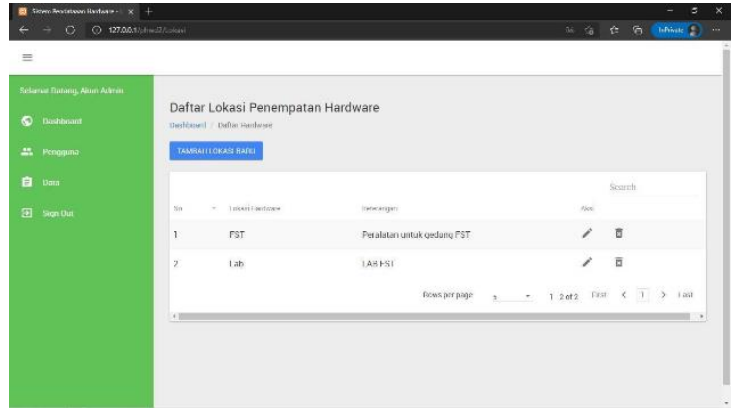

Gambar 10 Tampilan Halaman Daftar Lokasi Hardware

Pengujian sistem dilakukan dengan metode uji Blackbox dan User Acceptance Test (UAT). Untuk pengujian Blackbox didapatkan hasil sukses pada fungsi masingmasing menu dalam aplikasi ini. Dari pengujian Blackbox dinyatakan sistem berjalan dengan baik.

Metode pengujian UAT (User Acceptance Test) merupakan suatu metode pengujian oleh pengguna untuk menghasilkan sebuah dokumen yang bertujuan sebagai bukti bahwa sistem yang dibuat telah dapat diterima oleh pengguna. Pengujian UAT pada sistem ini dilakukan dengan mengajukan beberapa pertanyaan kepada dua pegawai perlengkapan, dan pengelola kepegawaian. Pada pengujian UAT ini terdapat 5 kategori yaitu SS (Sangat Setuju), S (Setuju), CS (Cukup Setuju), KS (Kurang Setuju), TS (Tidak Setuju). Berikut ini rincian hasil pengujian UAT.

Perhitungan pada total jawaban responden adalah sebagai berikut:

$\begin{array}{lll}\text { Sangat Setuju (SS) } & =5 \times 1 & =5 \\ \text { Setuju(S) } & =4 \times 12 & =48 \\ \text { Cukup Setuju (CS) } & =3 \times 11 & =33 \\ \text { Kurang Setuju (KS) } & =2 \times 0 & =0 \\ \text { Tidak Setuju (TS) } & =1 \times 0 & =0 \\ \text { Total Skor } & =\mathbf{8 6} & \end{array}$

Kemudian dilakukan perhitungan nilai $X$ (skor tertinggi) dan Y (skor terendah) sebagai berikut:

$\mathrm{X}=$ Skor tertinggi likert $\mathrm{x}$ Jumlah pernyataan $=5 \times 24=120$

$\mathrm{Y}=$ Skor terendah likert $\mathrm{x}$ Jumlah pernyataan
$=1 \times 24=24$

Setelah itu dilakukan perhitungan persentase UAT menggunakan persamaan rumus sebagai berikut:

$\mathrm{M}=\frac{86}{120} \times 100 \%=\mathbf{7 1 , 6 \%}$

Tabel berikut adalah range yang dapat dilihat sebagai kesimpulan dari persentase UAT yang telah dihitung:

Tabel 6.6 Tabel User Acceptance Test

\begin{tabular}{|l|l|l|}
\hline No. & Keterangan & Range \\
\hline 1 & Tidak Setuju & $0 \%-20 \%$ \\
\hline 2 & Kurang Setuju & $21 \%-40 \%$ \\
\hline 3 & Cukup Setuju & $41 \%-60 \%$ \\
\hline 4 & Setuju & $61 \%-80 \%$ \\
\hline 5 & Sangat Setuju & $81 \%-100 \%$ \\
\hline
\end{tabular}

Berdasarkan Tabel di atas, hasil pengujian termasuk kategori Setuju karena berada pada range $61 \%-80 \%$.

Setelah melakukan pengujian sistem dengan menggunakan metode-metode pengujian sistem (black box testing) dan User Acceptance Test (UAT), maka dapat disimpulkan bahwa Sistem Pendataan Hardware pada PTIPD UIN SUSKA RIAU sudah sesuai dengan yang diharapkan, semua menu dan juga komponen yang ada dalam sistem ini berhasil dijalankan.

Hasil dari laporan Perancangan dan Pembangunan Sistem Pendataan Hardware adalah memudahkan semua pihak yang terkait dalam melakukan pembuatan melakukan pendataan hardware masuk. Dapat disimpulkan pula Sistem Pendataan Hardware ini:

1. Sistem ini mampu mempermudah pengguna dalam mendata hardware yang ada pada PTIPD UIN SUSKA RIAU.

2. Berdasarkan pengujian yang telah dilakukan dengan black box Testing, maka Sistem Pendataan Hardware di PTIPD UIN SUSKA RIAU sudah 
berjalan sesuai dengan fungsional sebagaimana mestinya.

\section{SIMPULAN}

Setelah melakukan pengujian sistem dengan menggunakan metode-metode pengujian sistem (black box testing) dan User Acceptance Test (UAT), maka dapat disimpulkan bahwa Sistem Pendataan Hardware pada PTIPD UIN SUSKA RIAU sudah sesuai dengan yang diharapkan, semua menu dan juga komponen yang ada dalam sistem ini berhasil dijalankan.Berdasarkan pengajuan yang dilakukan dengan User Acceptance Test (UAT) memberikan hasil "Sangat Setuju" dengan skor $71,7 \%$.

\section{UCAPAN TERIMAKASIH}

Pada kesempatan ini Penulis ingin menyampaikan ucapan terimakasih kepada: Dosen Dosen Teknik Informatika UIN Suska Riau yang telah membimbing jalannya kerja praktek saya.

\section{DAFTAR PUSTAKA}

[1] M. R. Saputra and S. Ramadhani, "Sistem Informasi Bantuan Dana Hibah Operasional Rumah Ibadah Kabupaten Bengkalis," J. Teknol. dan Inf. Bisnis, vol. 3, no. 1, pp. 147152, 2021.

[2] M. R. Asyari and S. Ramadhani, "Sistem informasi arsip surat menyurat," J. Teknol. dan Inf. Bisnis, vol. 3, no. 1, pp. 175-184, 2021.

[3] F. Fawadhil and S. Ramadhani, "Rancang Bangun Sistem Informasi Pengaduan Layanan Teknis Bidang Teknologi Informasi dan Komunikasi," Semin. Nas. Teknol. Inf. Komun. dan Ind., no. 155, pp. 100-110, 2020.

[4] M. Ihsan and S. Ramadhani, "Sistem Informasi Pemetaan Pembangunan Kabupaten Indragiri Hilir," vol. 5, no. $1,2021$.
D. Azzahra and S. Ramadhani, "Pengembangan Aplikasi Online Public Access Catalog (Opac) Perpustakaan Berbasis Web Pada Stai Auliaurrasyiddin Tembilahan," J. Teknol. Dan Sist. Inf. Bisnis, vol. 2, no. 2, pp. 152-160, 2020, doi: 10.47233/jteksis.v2i2.127.

[6] M. R. Saputra, S. Ramadhani, and S Baru, "Sistem informasi bantuan dana hibah operasional rumah ibadah kabupaten bengkalis," J. Teknol. dan Inf. Bisnis, vol. 3, no. 1, p. 148, 2021.

[7] R. Siti, "Sistem Pencegahan Plagiarisme Tugas Akhir Menggunakan Algoritma RabinKarp (Studi Kasus: Sekolah Tinggi Teknik Payakumbuh)," J. Teknol. Inf. Komun. Digit. Zo., vol. 6, no. 1, pp. 44-52, 2015.

[8] N. Ikhsan and S. Ramadhani, "Sistem Informasi Administrasi Surat Menyurat Kantor Wilayah Kementrian Agama Provinsi Riau," J. Teknol. Dan Inf. Bisnis, vol. 2, no. 2, pp. 141-151, 2020.

[9] B. Arismanto and S. Rahmadhani, "Pengembangan Sistem Penerimaan Mahasiswa Baru pada STIES Imam Asy Syafii Pekanbaru," J. Intra-Tech, vol. 3, no. 1, pp. 57-72, 2019.

[10] M. Ridwan, Muhammad and S. Ramadhani, "Rancangan Sistem Informasi Manajemen Aset di PT . Sentral Tukang Indonesia," $J$. CoreIT, vol. 3, no. 2, pp. 47-53, 2017.

[11] D. Azzahra and S. Ramadhani, "Pengembangan Aplikasi Online Public Access Catalog (OPAC) Berbasis Web Pada STAI Auliaurrasyiddin Tembilanan," $J$. Teknol. Dan Sist. Inf. Bisnis, vol. 2, no. 2, pp. 152-160, 2020.

[12] R. A. Atmala and S. Ramadhani, "Rancang Bangun Sistem Informasi Surat Menyurat di Kementrian Agama Kabupaten Kampar," J. Intra 
Te ch, vol. 11, no. 2, pp. 56-62, 2018.

[13] Jogiyanto. 2008. Analisis dan Desain Sistem Informasi : Pendekatan Terstruktur Teori dan Praktek Aplikasi Bisnis. Yogyakarta: Andi.

[14] Winarno, Budi, 2014, Kebijakan Publik Teori, Proses dan Studi Kasus, Cetakan Kedua, CAPS, Yogyakarta.

[15] Bunafit, Nugroho, (2006), Membuat Aplikasi Sistem Pakar dengan PHP dan My SQL dengan PHP dan MySQL dengan Editor Dreamweaver, Ardana Media, Yogyakarta.

[16] Arief M Rudianto. 2011. Pemrograman Web Dinamis menggunakan PHP dan MySQL. C.V ANDI OFFSET. Yogyakarta.

[17] Handayaningrat, Soewarno. (1998). Pengantar Studi Ilmu Administrasi dan Manajemen. Jakarta: CV Haji Masagung

[18] Keraf, Gorys. 2001. Argumentasi dan Narasi. Jakarta: PT Gramedia Pustaka Utama.

[19] J. W. Satzinger, R. B. Jackson and S. D. Burd, Systems Analysis and Design in a Changing World, Sixth ed., 2011. 